\title{
Apakah pengendalian intern berpengaruh pada kualitas informasi laporan keuangan?
}

\author{
Endang Wahyuni, Sri Widodo \\ Universitas PGRI Yogyakarta \\ endangwahyuni789@gmail.com
}

\begin{abstract}
This research aims to determine the effect of accrual-based application, internal control, IT utilization and HR competency on the quality of financial statement information. The research is a quantitative approach with primary data source. The population in this research was 29 Organisasi Perangkat Daerah (OPD) of Sleman Regency. The sample in this research amounted to 107 respondents taken using a purposive sampling. Data collection in this research using a questionnare. The data analysis using a multiple regression. The result of this research show that the accrual-based application, IT utilization and HR competency have a positive effect on the quality of financial statement information, while internal control has no significant affect on the quality of financial statement information.
\end{abstract}

Key Words: Accrual-Based Application, Internal Control, IT Utilization, HR Competency, Quality Of Financial Statement Information

\section{Pendahuluan}

Salah satu fenomena yang berkaitan dengan perkembangan pemerintahan yang terjadi adalah tuntutan dari masyarakat yang semakin menguat atas penyelenggaraan pemerintahan yang baik (Good Coorporate Governance) sehingga memberikan dorongan kepada pemerintahan baik pusat maupun daerah agar akuntabilitas publik diterapkan dengan optimal (Modo et al., 2016). Salah satu bentuk keberhasilan pemerintah untuk mewujudkan akuntabilitas mengenai keuangan adalah menyampaikan pertanggungjawaban laporan melalui laporan keuangan (Eveline, 2017).

Laporan keuangan yang disampaikan pemerintah harus sesuai dengan SAP berbasis akrual yang tercantum dalam Peraturan Pemerintah Nomor 71 Tahun 2010 (Murapi, 2016). Kualitas laporan keuangan yang ditentukan oleh informasi yang tercantum didalamnya harus memenuhi karakteristik kualitatif yaitu relevan, andal, dapat dibandingkan, dapat dipahami (Safrizal \& Fitri, 2018). Fenomena mengenai kualitas laporan keuangan adalah topik menarik untuk pengkajian lebih lanjut. Laporan keuangan yang dihasilkan pemerintah ternyata masih menyajikan data yang tidak sesuai dengan kebenarannya. Pada saat pelaksanaan audit, BPK juga masih menemukan berbagai penyimpangan dalam laporan keuangan pemerintah (Marda et al., 2014).

Kabupaten Sleman merupakan salah satu kabupaten/kota yang mengalami peningkatan opini atas laporan keuangan pemerintah daerahnya. Bersumber dari IHPS II Tahun 2017 pada tahun 2012 sampai tahun 2016, Kabupaten Sleman mengalami peningkatan opini. Kabupaten Sleman mendapatkan opini Wajar Tanpa Pengecualian Dengan Paragraf Penjelas (WTP DPP) pada tahun 2012. Kabupaten Sleman pada tahun 2013 sampai tahun 2016 mengalami peningkatan kualitas laporan keuangan yaitu memperoleh opini Wajar Tanpa Pengecualian (WTP). 
Keberhasilan penyelenggaraan pemerintah dapat diwujudkan dengan sistem pengendalian intern yang tepat (Rahmawati et al., 2018). Pengendalian intern yang kuat sangat penting bagi suatu organisasi, apabila pengendalian intern dalam suatu organisasi lemah atau tidak tepat dalam implementasinya maka dapat menimbulkan kecurangan yang dilakukan oleh pihak internal organisasi sehingga akan merugikan organisasi itu sendiri (Sa'adah et al., 2017).

Salah satu kewajiban yang harus dilakukan pemerintah pusat dan pemerintah daerah yaitu pemanfaatan teknologi informasi berdasarkan Peraturan Pemerintah Nomor 56 Tahun 2005 (Ariesta, 2013). Manfaat dari TI yaitu seperti teknologi komputer, teknologi informasi dipergunakan untuk penyebaran data serta digunakan untuk pemrosesan data dan penyimpanan suatu informasi (Sari et al., 2016).

Kompetensi SDM merupakan suatu kemampuan yang dimiliki oleh individu dalam organisasi untuk melakukan tanggungjawabnya dalam mencapai tujuan dan sasaran suatu organisasi (Ihsanti, 2014). Tanggungjawab yang dimiliki seseorang dilihat berdasarkan deskripsi jabatan yang dipergunakan sebagai dasar dalam pelaksanaan tugas dan tanggungjawabnya sehingga dapat terselesaikan dengan baik dan benar (Yendrawati, 2013).

Berdasarkan penelitian sebelumnya yang meneliti mengenai kualitas informasi laporan keuangan menunjukkan hasil yang tidak konsisten. Penelitian Agustiawan and Rasmini (2016); Eveline (2017); Safrizal and Fitri (2018) membuktikan bahwa SAP berbasis akrual dapat meningkatkan kualitas informasi laporan keuangan. Penelitian Murapi (2016); Sari et al. (2016); Rahmawati et al. (2018) menyatakan bahwa pengendalian intern dapat menigkatkan kualitas informasi laporan keuangan. Yendrawati (2013) membuktikan bahwa pengendalian intern tidak dapat meningkatkan kualitas informasi laporan keuangan pemerintah daerah.

Penelitian Murapi (2016); Yosefrinaldi (2013); Azlan et al. (2015) membuktikan bahwa pemanfaatan TI dapat meningkatkan kualitas informasi laporan keuangan pemerintah, sedangkan Modo et al. (2016) membuktikan bahwa pemanfaatan TI tidak dapat meningkatkan kualitas informasi laporan keuangan. Penelitian Yosefrinaldi (2013); Azlan et al. (2015); Marda et al. (2014) membuktikan bahwa kompetensi SDM akan meningkatkan kualitas informasi laporan keuangan pemerintah daerah, sedangkan Murapi (2016) membuktikan bahwa kompetensi SDM tidak mampu meningkatkan kualitas informasi laporan keuangan pemerintah.

\section{Landasan teori dan pengembangan hipotesis}

\section{Kualitas Informasi Laporan Keuangan}

Laporan keuangan adalah laporan yang terstruktur berkaitan dengan posisi keuangan serta transaksi-transaksi yang dilaksanakan oleh suatu entitas pelaporan (Armel et al., 2017). Laporan keuangan dijadikan sebagai sarana dalam mencapai tujuan serta dalam pelaksanaan fungsi pertanggungjawaban suatu entitas (Mokoginta et al., 2017). Karakteristik kualitatif yang sesuai dengan PP 71 Tahun 2010 antara lain laporan keuangan yang relevan, andal, dapat dibandingkan dan dapat dipahami (Safrizal \& Fitri, 2018). 


\section{Penerapan SAP Berbasis Akrual}

Berdasarkan PP 71 Tahun 2010, SAP berbasis akrual merupakan SAP yang mengakui pendapatan, beban, aset, utang dan ekuitas dalam suatu pelaporan finansial yang berbasis akrual, serta pengakuan pendapatan, belanja dan pembiayaan dalam pelaporan pelaksanaan anggaran sesuai dengan basis yang telah ditetapkan sebelumnya dalam APBD atau APBN (Eveline, 2017). Tujuan utama dari penerapan basis akrual adalah untuk menghasilkan pengukuran kinerja yang lebih baik sehingga dapat mencapai tujuannya serta dapat memberikan fasilitas kepada manajemen keuangan atau aset menjadi lebih akuntabel dan transparan (Kiranayanti \& Erawati, 2016).

Penelitian Agustiawan and Rasmini (2016) menemukan bahwa penerapan SAP berbasis akrual yang semakin baik akan memberikan pengaruh positif pada kualitas informasi laporan keuangan. Sari et al. (2016) menemukan bahwa penerapan SAP berbasis akrual tidak berpengaruh terhadap kualitas laporan keuangan pemerintah. Kiranayanti and Erawati (2016); Rahmawati et al. (2018); Safrizal and Fitri (2018) menemukan bahwa basis akrual yang diterapkan secara baik sesuai dengan PP 71 Tahun 2010 dapat meningkatkan pemahaman SAP dalam menyajikan laporan keuangan sehingga terjadi peningkatan kualitas informasi laporan keuangan.

$H_{1}$ : Penerapan SAP berbasis akrual berpengaruh positif terhadap kualitas informasi laporan keuangan.

\section{Pengendalian Intern}

Berdasarkan PP 60 Tahun 2008, Pengendalian intern adalah suatu proses yang integral pada tindakan dan kegiatan dilakukan oleh pimpinan dan semua pegawai secara terus-menerus untuk memberikan suatu keyakinan yang memadai atas pencapaian tujuan organisasi melalui kegiatan yang efektif dan efisien, menjamin laporan keuangan menjadi lebih andal dan data keuangan, menjamin keamanan aset negara, memberikan jaminan kepatuhan terhadap hukum dan peraturan perundang-undangan (Budiawan \& Purnomo, 2014). Pengendalian intern dirancang dengan baik agar memberikan arahan dan pengawasan sumber daya organisasi untuk pencapaian tujuan secara efektif serta memiliki peran untuk mendeteksi dan mencegah kecurangan (Siwambudi et al., 2017).

Penelitian Yendrawati (2013) membuktikan bahwa pengendalian internal tidak dapat meningkatka kualitas laporan keuangan. Penelitian Agustiawan and Rasmini (2016); Eveline (2017); Murapi (2016) membuktikan bahwa pengendalian berpengaruh dapat meningkatkan kualitas informasi laporan keuangan. Meningkatnya kualitas informasi laporan keuangan apabila pengawasan intern yang diterapkan organisasi telah dilaksanakan dengan baik sehingga dapat mewujudkan tercapainya tujuan organisasi dalam menghasilkan laporan keuangan dengan kualitas yang baik (Modo et al., 2016).

$\mathrm{H}_{2}$ : Pengendalian intern berpengaruh positif terhadap kualitas informasi laporan keuangan.

\section{Pemanfaatan TI}

Pemerintah memiliki kewajiban untuk memanfaatkan teknologi informasi dan mengembangkannya sehingga kemampuan yang dimiliki berkaitan dengan pengelolaan keuangan akan semakin meningkat. Pemerintah juga memiliki berkewajiban dalam 
penyaluran informasi mengenai keuangan daerah kepada publik (Azlan et al., 2015). Menurut Wilkinson et al (2000) dalam Nurillah and Muid (2014) Pemanfaatan TI adalah penggunaan secara optimal dari teknologi informasi meliputi komputer, perangkat lunak, jaringan, database, electronic commerce, dan jenis lain berkaitan dengan TI. Komputer merupakan suatu alat yang dapat melipatgandakan kemampuan seseorang serta dapat membantu seseorang dalam melaksanakan kegiatan yang tidak dapat dilaksanakan oleh manusia itu sendiri (Sari et al., 2016). Pemanfaatan TI mencakup beberapa kegiatan seperti pengolahan data dan informasi, sistem manajemen dan proses kerja elektronik, serta seiring perkembangan kemajuan TI dalam masyarakat dapat dengan mudah untuk mengakses informasi pada pelayanan publik yang sudah memanfaatkan teknologi informasi (Chodijah \& Hidayah, 2018).

Penelitian Hardyansyah and Khalid (2016) membuktikan bahwa pemanfaatan TI dapat meningkatkan kualitas informasi laporan keuangan pemerintah. Semakin pesat kemajuan teknologi disertai dengan penggunaan teknologi informasi dalam pengelolaan keuangan dapat memberikan peluang bagi pengguna informasi dalam mengakses, mengelola dan menyalurkan informasi kepada masyarakat (Azlan et al., 2015; Modo et al., 2016). Penelitian Murapi (2016); Agustiawan and Rasmini (2016); Sari et al. (2016) menemukan bahwa meningkatnya pemanfaatan TI akan meningkatkan kualitas laporan keuangan pemerintah. $H_{3}$ : Pemanfaatan TI berpengaruh positif terhadap kualitas informasi laporan keuangan.

\section{Kompetensi SDM}

Kompetensi adalah karakteristik yang dimiliki oleh seseorang atau individu dalam organisasi berupa keterampilan (skill), kemampuan (ability) dan pengetahuan (knowledge) untuk menjalankan tugasnya dalam suatu pekerjaan (Harlinda, 2016). SDM yang berkompeten memiliki pemahaman yang lebih luas, oleh karena itu dalam penyusunan laporan keuangan mereka mampu menghasilkan laporan dengan kualitas yang lebih baik dengan memanfaatkan teknologi yang tersedia (Eveline, 2017). Penelitian Yosefrenaldi (2013) menyatakan bahwa kompetensi SDM akan meningkatkan kualitas laporan keuangan. Penelitian Modo et al. (2016); Mahaputra and Putra (2014); Ariesta (2013) menyatakan bahwa kompetensi SDM yang semakin baik akan meningkatkan kualitas informasi laporan keuangan yang dihasilkan pemerintah daerah.

$H_{4}$ : Kompetensi SDM berpengaruh positif terhadap kualitas informasi laporan keuangan.

\section{Metode penelitian}

\section{Definisi Operasional Variabel}

Kualitas informasi laporan keuangan adalah kemampuan informasi yang tercantum dalam laporan keuangan dapat dipahami dan dapat memenuhi kebutuhan pemakainya dalam pengambilan suatu keputusan, bebas dari pengertian yang menyesatkan dan kesalahan material, serta dapat diandalkan sehingga laporan keuangan dapat dibandingkan dengan periode-periode sebelumnya (Yosefrinaldi, 2013). Pengukuran menggunakan 4 indikator terdiri dari relevan, andal, dapat dibandingkan dan dapat dipahami (Safrizal \& Fitri, 2018).

Penerapan SAP berbasis akrual merupakan basis akuntansi yang mengakui pengaruh transaksi dan peristiwa lainnya pada saat transaksi dan peristiwa itu terjadi tanpa harus 
memperhatikan pada saat kas atau setara kas diterima atau dibayar (Agustiawan \& Rasmini, 2016). Diukur menggunakan 3 indikator yang dikembangkan oleh Lubis (2018) antara lain: 1) Laporan keuangan disusun secara periodic, 2) Evaluasi atas pelaporan keuangan, 3) Keterbukaan dan kejujuran dari laporan keuangan.

Pengendalian intern merupakan koordinasi antara struktur organisasi, metode dan ukuran agar kekayaan organisasi tetap terjaga, pengecekan ketelitian dan keandalan data akuntansi dan mendorong efisiensi serta meningkatkan kepatuhan terhadap kebijakan manajemen (Mokoginta et al., 2017). Diukur menggunakan 5 indikator yang dikembangkan oleh Yosefrinaldi (2013) antara lain: 1) Lingkungan pengendalian, 2) Penilaian resiko, 3) Kegiatan pengendalian, 4) Informasi dan komunikasi, 5) Pemantauan.

Pemanfaatan TI merupakan suatu harapan dari para pemakai informasi dalam melaksanakan tugasnya agar memperoleh manfaat (Ariesta, 2013). Indikator pemanfaatan TI dilihat dari 1) Ketersediaan perangkat komputer dan jaringan internet di setiap OPD, 2) Pemanfaatan jaringan internet sebagai penghubung dalam pertukaran data, 3) Penggunaan software sesuai dengan peraturan perundang-undangan untuk pengolahan data transaksi keuangan dan adanya proses akuntansi dan pembuatan laporan keuangan yang terkomputerisasi sehingga menghasilkan laporan akuntansi yang terintegrasi, 4) Adanya pemeliharaan peralatan secara teratur (Yosefrinaldi, 2013).

Kompetensi SDM merupakan suatu kemampuan yang dimiliki SDM untuk melakukan setiap tugas dan tanggungjawabnya melalui ilmu pendidikan, pelatihan dan pengalaman yang cukup memadai (Yosefrinaldi, 2013). Diukur menggunakan 3 indikator yang dikembangkan oleh Yosefrinaldi (2013) meliputi: latar belakang pendidikan, pelatihan dan pengalaman.

\section{Populasi dan Sampel}

Populasi penelitian adalah 29 OPD Kabupaten Sleman meliputi Dinas, Badan, Sekretariat Daerah, Sekretariat DPRD dan Inspektorat Kabupaten. Pengambilan sampel menggunakan purposive sampling, yaitu metode pengambilan sampel menggunakan kriteria yang ditentukan oleh penulis (Sugiyono, 2016). Setiap OPD diambil 4 responden dengan kriteria Kepala OPD, Kabag/Kasubbag Keuangan, Bendahara Penerimaan dan Bendahara Pengeluaran. Data primer diperoleh dengan menyebarkan kuesioner secara langsung kepada responden. Sehingga sampel yang digunakan dalam penelitian ini sebanyak 107 responden.

\section{Hasil dan pembahasan}

\section{Hasil pengujian validitas \& reliabilitas}

Pengujian kualitas data dilakukan dengan memberikan pertanyaan yang dibagi menjadi 4 variabel independen dan 1 variabel independen. 8 pertanyaan untuk $\left(\mathrm{X}_{1}\right), 10$ pertanyaan untuk $\left(\mathrm{X}_{2}\right), 8$ pertanyaan untuk $\left(\mathrm{X}_{3}\right), 9$ pertanyaan untuk $\left(\mathrm{X}_{4}\right), 9$ pertanyaan untuk $(\mathrm{Y})$. Hasil pengujian validitas menunjukkan bahwa seluruh instrumen pertanyaan yang diajukan dinyatakan valid, dilihat dari tingkat signifikansi kualitas data sebesar $0,000<0,05$. Hasil uji reliabilitas menunjukkan bahwa semua instrumen jawaban responden memiliki nilai Cronbach alpha lebih besar dari 0,06 sehingga dapat diambil kesimpulan bahwa semua instrumen jawaban responden dinyatakan reliabel. 
Tabel 1. Hasil uji reliabilitas

\begin{tabular}{lc}
\hline \multicolumn{1}{c}{ Variabel } & Cronbach Alpha \\
\hline Penerapan SAP Berbasis Akrual & 0,910 \\
Pengendalian Intern & 0,846 \\
Pemanfaatan TI & 0,894 \\
Kompetensi SDM & 0,838 \\
Kualitas Informasi Laporan Keuangan & 0,903 \\
\hline Sumber: Data Primer Diolah Tahun 2019
\end{tabular}

\section{Hasil Pengujian Hipotesis}

Hasil uji t untuk variabel penerapan SAP berbasis akrual dengan nilai $p$ value sebesar 0,000 $<0,05$ sehingga Hipotesis pertama $\left(\mathrm{H}_{1}\right)$ diterima. Hasil uji t variabel pengendalian intern dengan nilai $p$ value sebesar $0,052>0,05$ sehingga Hipotesis kedua $\left(\mathrm{H}_{2}\right)$ ditolak yang berarti bahwa variabel tidak berpengaruh. Hasil uji t variabel pemanfaatan TI dengan nilai $p$ value sebesar $0,010<0,05$ sehingga Hipotesis ketiga $\left(\mathrm{H}_{3}\right)$ diterima. Hasil uji t variabel kompetensi SDM dengan nilai $p$ value sebesar $0,000<0,05$ sehingga Hipotesis keempat $\left(\mathrm{H}_{4}\right)$ diterima.

Tabel 2. Hasil uji hipotesis

\begin{tabular}{lccl}
\hline \multicolumn{1}{c}{ Variabel } & B & P Value & \multicolumn{1}{c}{ Hasil } \\
\hline (Constant) & $-1,193$ & 0,650 & \\
Penerapan SAP Berbasis Akrual & 0,308 & 0,000 & $\mathrm{H}_{1}=$ Diterima \\
Pengendalian Intern & 0,213 & 0,052 & $\mathrm{H}_{2}=$ Ditolak \\
Pemanfaatan TI & 0,250 & 0,010 & $\mathrm{H}_{3}=$ Diterima \\
Kompetensi SDM & 0,298 & 0,000 & $\mathrm{H}_{4}=$ Diterima \\
\hline F Hitung $=$ 67,985 & & 0,000 & \\
Adjusted $R$ Square $=0,717$ & & \\
Sumber Data Primer diolah Tahun 2019 & &
\end{tabular}

\section{Pembahasan}

Variabel penerapan SAP berbasis akrual berpengaruh positif terhadap kualitas informasi laporan keuangan. Hasil penelitian ini sejalan dengan penelitian sebelumnya (Eveline, 2017; Lubis, 2018; Rahmawati et al., 2018) yang menemukan bahwa penerapan standar akuntansi berbasis berbasis akrual berpengaruh positif terhadap kualitas informasi laporan keuangan. Organisasi yang telah menerapkan basis akrual berdasarkan peraturan yang ditetapkan yaitu PP 71 Tahun 2010 lebih mudah dalam menghasilkan laporan keuangan pemerintah dengan kualitas yang baik sesuai dengan kriteria yang diinginkan dalam suatu organisasi (Safrizal \& Fitri, 2018). Penerapan SAP secara konsisten sangat membantu organisasi untuk mengurangi tingkat kesalahan pada saat menyajikan laporan keuangan sehingga kualitas informasi laporan keuangan dapat meningkat (Agustiawan \& Rasmini, 2016).

Variabel pengendalian intern tidak berpengaruh terhadap kualitas informasi laporan keuangan. Hasil penelitian ini mendukung penelitian sebelumnya (Budiawan \& Purnomo, 2014; Yendrawati, 2013) yang menemukan bahwa pengendalian intern tidak berpengaruh terhadap kualitas informasi laporan keuangan. Organisasi harus menetapkan pengendalian intern sesuai dengan PP 80 Tahun 2005 karena pengendalian intern yang diterapkan dalam organisasi kurang baik akan sangat berpengaruh terhadap kualitas informasi laporan keuangan yang dihasilkan pemerintah (Rokhlinasari \& Hidayat, 2016). Pengendalian intern 
yang sudah ditetapkan dengan lebih baik tetapi tidak diterapkan secara konsisten akan menghasilkan informasi laporan keuangan yang kurang tepat (Mokoginta et al., 2017).

Variabel pemanfaatan TI berpengaruh positif terhadap kualitas informasi laporan keuangan. Hasil penelitian ini sejalan dengan penelitian sebelumnya (Rahmawati et al., 2018; Sari et al., 2016; Yosefrinaldi, 2013) menemukan bahwa pemanfaatan TI berpengaruh positif terhadap kualitas informasi laporan keuangan pemerintah daerah. Agustiawan and Rasmini (2016) menyatakan bahwa adanya pemanfaatan teknologi dalam mengelola keuangan untuk menghasilkan laporan dapat meningkatkan pemrosesan suatu transaksi, keakuratan dalam perhitungan mengenai keuangan, serta penyiapan laporan yang lebih tepat waktu.

Variabel kompetensi SDM berpengaruh terhadap kualitas informasi laporan keuangan. Hasil penelitian ini mendukung penelitian sebelumnya (Sari et al., 2016; Yosefrinaldi, 2013) menemukan bahwa kompetensi SDM berpengaruh positif terhadap kualitas informasi laporan keuangan pemerintah. Pembinaan berupa pelatihan maupun pendidikan terhadap staf pemerintah daerah maupun pimpinan OPD dapat meningkatkan kompetensi atau keahlian SDM sehingga terjadi peningkatan kualitas laporan keuangan (Modo et al., 2016).

\section{PENUTUP}

\section{Simpulan}

Hasil penelitian ini dapat disimpulkan bahwa penerapan SAP berbasis akrual, pemanfaatan TI dan kompetensi SDM berpengaruh positif terhadap variabel kualitas informasi laporan keuangan, sedangkan pengendalian intern tidak berpengaruh terhadap variabel kualitas informasi laporan keuangan.

\section{Saran}

1. Penelitian selanjutnya diharapkan dapat memperluas wilayah penelitian di daerah lain karena cakupan wilayah yang lebih luas dapat memberikan gambaran secara menyeluruh mengenai kualitas informasi laporan keuangan pemerintah di daerah lainnya (Ariesta, 2013).

2. Penelitian selanjutnya dapat memberikan tambahan variabel lain seperti sistem informasi akuntansi, komitmen dan budaya organisasi (Yendrawati, 2013).

3. Penelitian selanjutnya agar menggunakan metode wawancara karena jawaban responden secara lisan dapat menggambarkan keadaan yang sebenarnya sehingga dapat memperoleh data yang lebih lengkap (Armel et al., 2017).

\section{DAFTAR PUSTAKA}

Agustiawan, N. T., \& Rasmini, N. K. (2016). Pengaruh Sistem Berbasis Akrual, TI, dan SPIP Pada Kualitas Laporan Keuangan dengan Kompetensi SDM Sebagai Moderasi. E-Jurnal Ekonomi dan Bisnis Universitas Udayana, 5(10 ), 3475-3500.

Ariesta, F. (2013). Pengaruh Kualitas Sumber Daya Manusia, Pemanfaatan Teknologi Informasi, dan Pengendalian Intern Akuntansi Terhadap Nilai Informasi Pelaporan Keuangan Pemerintah Daerah (Studi pada Satuan Kerja Perangkat Daerah di Kabupaten Pasaman Barat. Jurnal Akuntansi, 1(1), 40-63.

Armel, R. Y. G., Nasir, A., \& Safitri, D. (2017). Pengaruh Kompetensi Sumber Daya Manusia, Penerapan Standar Akuntansi Pemerintahan, Pemanfaatan Teknologi 
Informasi dan Sistem Pengendalian Internal Terhadap Kualitas Laporan Keuangan Pemerintah Daerah (Studi Pada Satuan Kerja Perangkat Daerah Kota Dumai). Jurnal Online Mahasiswa Fakultas Ekonomi, 4(1), 105-119.

Azlan, M., Herwanti, T., \& Pituringsih, E. (2015). Pengaruh Kualitas Sumber Daya Manusia, Pemanfaatan Teknologi Informasi, Pengendalian Intern dan Pengawasan Keuangan Daerah Terhadap Keandalan Laporan Keuangan Daerah Pada SKPD Pemerintah Kabupaten Lombok Timur. Jurnal Akuntansi Aktual, 3(2), 188-198.

Budiawan, D. A., \& Purnomo, B. S. (2014). Pengaruh Sitem Pengendalian Internal dan Kekuatan Koersif Terhadap Kualitas Laporan Keuangan Pemerintah Daerah. Jurnal Riset dan Akuntansi Keuangan, 2(1), 276-288.

Chodijah, S., \& Hidayah, N. (2018). Pengaruh Pemanfaatan Teknologi Informasi dan Sistem Pengendalian Internal terhadap Kualitas Pelaporan Keuangan Pemerintah Daerah (Studi Kasus SKPD Provinsi DKI Jakarta). Jurnal Tekun, 8(1), 34-48.

Eveline, F. (2017). Pengaruh SAP Berbasis Akrual, Sistem Informasi Akuntansi, Kualitas SDM, Pengendalian Internal dan Komitmen Organisasi terhadap Kualitas Laporan Keuangan di Badan Nasional Penanggulangan Bencana. Media Riset Akuntansi, Auditing \& Informasi, 16(1), 1-14.

Hardyansyah, \& Khalid, A. (2016). Pengaruh Kompetensi Sumber Daya Manusia Dan Pemanfaatan Teknologi Informasi Terhadap Kualitas Laporan Keuangan Dengan Sistem Pengendalian Intern Sebagai Variabel Moderasi Pada SKPD Kabupaten Polewali Mandar. Akuntansi Peradaban, 1(1), 41-65.

Harlinda. (2016). Analisis Faktor yang Mempengaruhi Kualitas Informasi Laporan Keuangan Pemerintah Daerah (Studi Empiris pada Pemerintah Kabupaten/Kota di Provinsi Riau). Jurnal Sorot, 11(2), 127 - 144.

Ihsanti, E. (2014). Pengaruh Kompetensi Sumber Daya Manusia dan Penerapan Sistem Akuntansi Keuangan Daerah Terhadap Kualitas Laporan Keuangan Daerah (Studi Empiris pada SKPD Kab. Lima Puluh Kota). Jurnal Akuntansi, 2(3), 1163-1182.

Kiranayanti, I. A. E., \& Erawati, N. M. A. (2016). Pengaruh Sumber Daya Manusia, Sistem Pengendalian Intern, Pemahaman Basis Akrual Terhadap Kualitas Laporan Keuangan Daerah. E-Jurnal Akuntansi, 16(2), 1290-1318.

Lubis, M. (2018). Pengaruh Kompetensi Sumber Daya Manusia, Pemanfaatan Teknologi Informasi, Penerapan SAP Berbasis Akrual, dan Penerapan Sistem Pengendalian Intern Pemerintah Terhadap Kualitas Laporan Keuangan Pemerintah Pada Satuan Kerja Kanwil Kementrian Agama Provinsi Sumatera Utara (Tesis). Universitas Sumatera Utara.

Mahaputra, I. P. U. R., \& Putra, I. W. (2014). Analisis Faktor-Faktor yang Mempengaruhi Kualitas Informasi Laporan Keuangan Pemerintah Daerah. E-Jurnal Akuntansi, 8(2), 230-244.

Marda, G. S., Raja Adri Satriawan, S., MA, Ak, \& Supriono, S., M.Si, Ak. (2014). Pengaruh Sumber Daya Manusia, Pemanfaatan Teknologi Informasi dan Pengawasan Keuangan Daerah Terhadap Keandalan Pelaporan Keuangan Pemerintah Kota Dumai. Jurnal Online Mahasiswa (JOM) Bidang Ilmu Ekonomi, 1(1), 1-15.

Modo, S. M., Saerang, D. P. E., \& Poputra, A. T. (2016). Analisis Faktor-Faktor yang Mempengaruhi Kualitas Informasi Laporan Keuangan Pemerintah Daerah (Studi 
Empiris Pada SKPD Pemerintah Kabupaten Kepulauan Talaud). Jurnal Riset Akuntansi dan Auditing Goodwill, 7(2), 14-30.

Mokoginta, N., Lambey, L., \& Pontoh, W. (2017). Pengaruh Sistem Pengendalian Intern dan Sistem Akuntansi Keuangan Daerah terhadap Kualitas Laporan Keuangan Pemerintah. Jurnal Riset Akuntansi Going Concern, 12(2), 874-890.

Murapi, I. (2016). Faktor-Faktor yang Mempengaruhi Kualitas Informasi Laporan Keuangan Pemerintah Daerah (Studi Empiris pada SKPD di Kabupaten Lombok Tengah). Jurnal Infestasi, 12(2), 131-143.

Nurillah, A. S., \& Muid, D. (2014). Pengaruh Kompetensi Sumber Daya Manusia, Penerapan Sistem Akuntansi Keuangan Daerah (SAKD), Pemanfaatan Teknologi Informasi, dan Sistem Pengendalian Intern Terhadap Kualitas Laporan Keuangan Pemerintah Daerah (Studi Empiris Pada SKPD Kota Depok). Diponegoro Journal of Accounting, 3(2), 2337-3806.

Peraturan Pemerintah Nomor 56 Tahun 2005. Tentang Sistem Informasi Keuangan Daerah.

Peraturan Pemerintah Nomor 60 Tahun 2008. Tentang Sistem Pengendalian Intern Pemerintah.

Peraturan Pemerintah Nomor 71 Tahun 2010. Tentang Standar Akuntansi Pemerintahan Berbasis Akrual.

Rahmawati, A., Mustika, I. W., \& Eka, L. H. (2018). Pengaruh Penerapan Standar Akuntansi Pemerintah, Pemanfaatan Teknologi Informasi, dan Sistem Pengendalian Intern terhadap Kualitas Laporan Keuangan SKPD Kota Tangerang Selatan. Jurnal Ekonomi Bisnis dan Akuntansi (JEBA), 20(2), 8-17.

Rokhlinasari, S., \& Hidayat, A. (2016). Pengaruh Sistem Pengendalian Intern Terhadap Kualitas Laporan Keuangan Pada Bank BJB Syariah Cirebon. Al-Amwal, 8(2), 491508.

Sa'adah, K., Sitawati, R., \& Subchan. (2017). Pengaruh Kompetensi Sumber Daya Manusia dan Sistem Pengendalian Intern terhadap Kualitas Informasi Laporan Keuangan dengan Moderasi Pemanfaatan Teknologi Informasi. Jurnal Ilmu Manajemen dan Akuntansi Terapan, 8(2), 64-79.

Safrizal, N., \& Fitri, F. A. (2018). Analisis Penerapan Standar Akuntansi Pemerintahan, Pengendalian Internal, dan Kualitas Laporan Keuangan (Studi Pada SKPD Bener Meriah). Jurnal Ilmiah Mahasiswa Ekonomi Akuntansi, 3(1), 37-43.

Sari, N., Hasan, A., \& Diyanto, V. (2016). Pengaruh Kapasitas Sumber Daya Manusia, Pemahaman Akuntansi, Penerapan SAP, Pemanfaatan Teknologi Informasi, dan Sistem Pengendalian Intern terhadap Kualitas Laporan Keuangan Pemerintah Daerah (Studi Empiris Pada Satuan Kerja Perangkat Daerah Kabupaten Bungo. Jurnal Online Mahasiswa Fakultas Ekonomi Universitas Riau, 3(1), 1478-1490.

Siwambudi, I. G. N., Yasa, G. W., \& Badera, I. D. N. (2017). Komitmen Organisasi sebagai Pemoderasi Pengaruh Kompetensi SDM dan Sistem Pengendalian Intern pada Kualitas Laporan Keuangan. E-Jurnal Ekonomi dan Bisnis Universitas Udayana, 6(1), 385-416.

Sugiyono. (2016). Metode Penelitian Kuantitatif kualitatif dan $R \& D$. Bandung: CV Alfabeta. 
Yendrawati, R. (2013). Pengaruh Sistem Pengendalian Intern dan Kapasitas Sumber Daya Manusia terhadap Kualitas Informasi Laporan Keuangan dengan Faktor Eksternal Sebagai Variabel Moderating. Jurnal Akuntansi dan Auditing Indonesia. Jurnal Akuntansi dan Auditing Indonesia, 17(2),, 17(2), 166-175.

Yosefrinaldi. (2013). Pengaruh Kapasitas Sumber Daya Manusia dan Pemanfaatan Teknologi Informasi terhadap Kualitas Laporan Keuangan Pemerintah Daerah dengan Variabel Intervening Sistem Pengendalian Intern Pemerintah (Studi Empiris Pada Dinas Pengelolaan Keuangan dan Aset Daerah. Jurnal Akuntansi, 1(1), 54-77. 